\title{
An Accounting Viewpoint for the Relationship Between Intellectual Capital and Web Trends of BIST 30 Firms in Turkey
}

\author{
Cevdet KIZIL ${ }^{\star}$ M. Lütfi ARSLAN ${ }^{\star \star}$ - Şadi Evren SEKER ${ }^{\star \star \star}$
}

Öz

Bu araştırmada, bist-30 endeksine' dahil işletmelerin entelektüel sermayeleri ile web trendleri arasındaki ilişki muhasebe bakış açısıyla incelenmiştir. Bilindiği üzere, bist-30 Borsa îstanbul'da listelenen önde gelen 30 şirketten oluşmaktadır. Firmaların ve web sitelerinin trendleri, Google Trends gibi spesifik web araçları kullanılarak analiz edilmiştir. Aynı zamanda, entelektüel sermayeyi ölçmek için Piyasa Değeri / Defter Değeri ve Katma Değer Entelektüel Katsayısı (KDEK) yöntemlerinden yararlanılmıştır. Bunun yanında, entelektüel sermayenin muhasebeleştirimesi ve ölçülmesi amacıyla şirket web sitelerine, firma faaliyet raporlarına, işletme mali tablolarına ve Kamuyu Aydınlatma Platformu'na ${ }^{2}$ da başvurulmuştur.

Anahtar Kelimeler: Muhasebe, Finansal Raporlama, Ölçme, Entelektüel Sermaye, Borsa, Veri Madenciliği, Zaman Serisi Analizi, Faaliyet Raporları

\footnotetext{
Yard. Doç. Dr., Yalova University Business Administration Department in English, cevdetkizil@yahoo.com

* Doç. Dr.,Istanbul Medeniyet University Business Management Department, lutfi.arslan@medeniyet.edu.tr

*** Yard. Doç. Dr., Istanbul Medeniyet University Business Management Department, academic@sadievrenseker.com

By April 2013, IMKB30 index has been substituted by BIST30 index after the name of Istanbul Stock Market, that changed from IMKB to BIST

Kamuyu Aydınlatma Platformu (www.kap.gov.tr)
} 


\section{Abstract}

This research investigates the relationship between intellectual capital and web trends of the index bist- $30^{3}$ from an accounting viewpoint. As well known, bist-30 is comprised of top 30 firms listed in Istanbul Stock Exchange. The trends of web pages and firm are analyzed using specific web means such as the Google Trends. In addition, Market Value / Book Value and Value Added Intellectual Coefficient (VAIC) methods are utilized to measure intellectual capital. Also, enterprise web sites, firm annual reports, company financial statements and Public Disclosure Platform ${ }^{4}$ are taken advantage for accounting and measurement of intellectual capital.

Keywords: Accounting, Financial Reporting, Measurment, Intellectual Capital, Stock Exchange, Data Mining, Time Series Analysis, Operating Reports

\section{Introduction}

Intellectual capital is currently a popular and extensively discussed topic. In the past, enterprises were solely considered and evaluated by their phyiscal and tangible assets. On the other hand, the knowledge era requires a much accurate consideration of firms' real value. That is the leading reason why intellectual capital plays a critical value for companies and nations. ${ }^{5}$

It is evident that ignoring intellectual capital is equivalent to only seeing the top of an iceberg. But, stakeholders of the modern business era can never be satisfied at this point. In fact, stakeholders are represented with a wide spectrum, that

\footnotetext{
By April 2013, IMKB30 index has been substituted by BIST30 index after the name of Istanbul Stock Market, that changed from IMKB to BIST

Kamuyu Aydınlatma Platformu (www.kap.gov.tr)

5 Agndal H, and Nilsson U. (2006), "Generation of Human and Structural Capital: Lessons from Knowledge Management", The Electronic Journal of Knowledge Management, Volume 4 Issue 2, pp 91 - 98, available online at www.ejkm.com.
} 
can be listed as the government, entrepreneurs, banks, creditors, rivals, managers, employees, investors, shareholders and so on. All of the mentioned stakeholders need to have the most accurate and detailed information about the firm. ${ }^{6}$

Intellectual capital is nowadays an important tool for governments to reach to important conclusions about firms. Moreover, since intellectual capital reflects the real value of an enterprise, investors use it for merger, acquisition and privatization decisions. Plus, conditions are better for firms armed with strong intellectual capital, when they aim to get credits cheaper with lower rates. In fact, that is very natural because stong intellectual capital is considered as lower risk, core competence and comparative advantage. Then, rival firms can form better action plans when they are informed about intellectual capital of enterprises operating in a specific fector. ${ }^{7}$

Also, managers have the opportunity to take necessary actions and give a better direction to their enterprises in case they are informed about their organization's intellectual capital. In other words, intellectual capital provides them the big picture and serves as an essential part of firm strategy. Besides, when intellectual capital of organizations is shared with the public, employees are armed with additional information, which leads them through an efficient job application and career path. Likewise, companies with strong intellectual capital have the chance to recruit and retain higher quality personnel. ${ }^{8}$

Investors and shareholders can also give more wise decisions when they purchase the stocks of organizations listed in

\footnotetext{
Mayo, A. (2000), "The role of employee development in the growth of intellectual capital", Personnel Review, Vol. 29 Issue: 4, pp.521 - 533.

7 Riahi-Belkaoui, A. (2003)i "Intellectual capital and firm performance of US multinational firms: A study of the resource-based and stakeholder views", Journal of Intellectual Capital, Vol. 4 Issue: 2, pp.215-226.

8 Nahapiet, J, and Ghoshal, S. (1998), "Social Capital, Intellectual Capital and the Organizational Advantage", Academy of Management, The Academy of Management Review, Vol. 3 No: 2, p. 242-266.
} 
stock exchange. Definitely, intellectual capital enlightens investors and shareholders with a broader perspective about the growth and improvement trend as well as potential of an organization. Parallel to this issue, it is stated that sharing intellectual capital information of companies is also advantageous for the economy of nations, since investments are allocated much better. ${ }^{9}$

Accounting, reporting and measuring intellectual capital have became critical requirements for firms and the concerned stakeholders today. These are no longer extras considering the characteristics of today's knowledge age ${ }^{10}$. That is one of the leading motivations why this study focuses on intellectual capital of top thirty enterprises in Turkey.

The research deals with the emphasized top thirty, since these enterprises give a direction to the markets. This means, these firms highlight the structure of Turkish economy. Further, the web trends aspect is also included in this study, since the relationship between intellectual capital and technology is evident. When the three components of intellectual capital are taken into account, the web trends of top thirty firms in Turkey have stronger connections with relational capital and structural capital. $^{11}$

This study is centered on web statistics of the enterprises on BIST30. Accounting and measurement of intellectual capital of enterprises are investigated by benefiting from firm annual reports and company financial statements like the balance sheet and income statement. These are shared and viewed on company web sites, since the aformentioned firms are publicly traded companies. Additionally, Public Disclosure Platform

9 Guthrie, J, Petty, R, Ricceri, F. (2006), "The voluntary reporting of intellectual capital: Comparing evidence from Hong Kong and Australia", Journal of Intellectual Capital, Vol. 7, Issue: 2, pp.254 - 271

10 Alipour, M. (2012), "The effect of intellectual capital on firm performance: an investigation of Iran insurance companies", Measuring Business Excellence, Vol. 16, Issue: 1, pp.53- 66 .

11 Joia, L. A. (2007), "Strategies for Information Technology and Intellectual Capital: Challanges and Opportunities", IGI Global, pp. 1-276. 
powered by BIST administration also makes it a requirement to share financial and accounting information with the society. ${ }^{12}$ Besides, according to the newly passed commercial law, all enterprises should be completely transparent by having publicly accessible financial statements and establishing firm websites. ${ }^{13}$ This paper progresses as follows: Literature review, data and methodology, statistical and accounting analysis, results (findings), conclusion and recommendations for future studies.

\section{Literature Review}

Intellectual capital is tightly related with the concept of knowledge. Some authorities defend that, intellectual capital is the end outcome of knowledge transformation process. ${ }^{14}$ At this point, it is argued that intellectual capital and knowledge of an organization are critical in terms of competition, continuous improvement and efficiency. ${ }^{15}$ Thus, the importance of intellectual capital has seriously increased in the recent years, since the gap between market values and book values of firms is getting wider. ${ }^{16}$ Especially between the late 1990 s and early 2000s, firms with intangible assets highered tremendously. A large portion of the value of these firms were linked to their intangible assets instead of tangible and phsyiscal assets. ${ }^{17}$

12 Borsa istanbul (2013), "Kamuyu Aydınlatma Platformu", Borsa istanbul Official Website,

http://borsaistanbul.com/data/Kilavuzlar/Borsa_Istanbul_Kamuyu_Aydinlatma_Pla tformu.pdf (September 25, 2013).

13 Meral, R. (2013), "Yeni Türk Ticaret Kanunu Rehberi: Yeni Ticaret Kanunu ve iş Dünyası", ALBiAD (Alanya Birleşik Işadamları Derneği) Websitesi,

http://www. albiad.org/bilgi-merkezi/yeni-turk-ticaret-kanunu-rehberi.html (September 25, 2013).

14 CIMA. (2008), "Management accounting: Decision making", Fifth edition. London: BPP Learning Media.

15 Ordóñez de Pablos, P. (2004), "Measuring and reporting structural capital: Lessons from European learning firms", Journal of Intellectual Capital, 5(4), p. 629.

16 Sullivan, P. H. (2000), "Value-Driven Intellectual Capital: How to Convert Intangible Corporate Assets into Market Value", John Wiley \& Sons Inc., New York, pp. 4-7.

17 Sullivan, P. H. Jr. and Sullivan P. H. Sr. (2001), "Valuing intangibles companies: An intellectual capital approach", Journal of Intellectual Capital, 1(4), pp. 328340 . 
Although intellectual capital continues to be a hot topic and the firms with rich intangibles go up, subjective and inadequate practices related to accounting, reporting and measurement of intellectual capital continues to a leading issue. ${ }^{18}$ This means that, non-disclosure of intellectual capital in addition to not showing innovation and knowledge on financial statements go on to be a big obstacle for presenting the real value of enterprises. Accounting-finance theoricians as well as practicians still argue about how to state profits resulting from intangible assets on balance sheets and income statements. ${ }^{19}$ Classical financial statements are unfortunately still founded on book values of enterprises, eliminating the market values. Despite the fact that, the market value may not always be identical to intellectual capital ${ }^{20}$, the gap between book value and market value is crtical to stress the existence and influence of intellectual capital. ${ }^{21}$ The roots and arguments related to intellectual capital date back to 1960s and the discussions about human capital investments date back to 1990s. However, answers to many questions are still non-existent. ${ }^{22}$

But, the present strict requirements by International Accounting Standards also lead the emphasized questions to remain unanswered. Accounting is founded on objectivity, consistency, verifiability and comparability rules. Thus, there is no room for subjectivity and alteration of financial-accounting information by managers. ${ }^{23}$ However, there is a vital necessity to report intangibles and show the real value of organizations to investors and other parties. ${ }^{24}$ Accounting nowadays receives

18 Moolman, S. (2011), "Intellectual Capital: Measurement, Recognition and Reporting", University of South Africa Master in Commerce Graduate Thesis, p. 2.

19 Holland, J. (2006), "Fund management, intellectual capital, intangibles and private disclosure", Managerial Finance, 32(4), p.281.

20 Steward, T. A. (2001), "Accounting gets radical", Fortune, 143(8), pp. 184-194.

21 Rodov I. and Leliaert P. (2002), "FiMIAM: Financial method of intangible assets measurement", Journal of Intellectual Capital, 3(3), p. 324.

22 Marr B. and Moustaghfir K. (2005), "Defining intellectual capital: A threedimensional approach", Management Decision, 43(9), p. 1120.

23 IASB. (2010), "International Financial Reporting Standards (IFRSs)", Vol 1A \& 1B, London, B1719.

24 Moolman, S. (2011), "Intellectual Capital: Measurement, Recognition and Reporting", University of South Africa Master in Commerce Graduate Thesis, p. 6. 
criticism for not reporting the accurate value of enterprises on financial statements. ${ }^{25}$

The economy has transformed from an industrial economy to a knowledge based economy. So, the classical factors of production lost their general acceptance. The classical factors of production are listed as capital, land and labor. But, the business world of our era also definitely consists knowledge as a main factor of production. That is observed as higher educated and bigger cost personnel in the business world. Hiring several personnel is now out of fashion and hiring talented employees with low turnover ratio is preferred. Thus, managing intagible assets is an extensively discusses topic today, which triggers several publications and practices. ${ }^{26}$

From a wider perspective, intellectual capital means a network of inter-relations in a specific organization. Thus, coordinating intangible resources, creativity and feedback in addition to transforming these to value are very important concerning intellectual capital. This means that, intellectual capital assists to connect these components and starts the efficiency flow in enterprises. It is critical to develop and manage intellectual capital in enterprises in addition to create an unorthodox intellectual capital character for all organizations. ${ }^{27}$

According to the relevant literature, intellectual capital is classified as human capital, structural capital and relational (customer) capital. ${ }^{28} 29$ Human capital is equivalent to the tal-

25 Roslender, R. and Fincham R. (2004), "Intellectual capital accounting in the UK", Accounting, Auditing \& Accountability Journal, 17(2): p. 178.

26 Seetharaman A, Balachandran M. and Saravanan A. S. (2002), "Accounting treatment of goodwill: Yesterday, today and tomorrow: Problems and prospects in the international perspective", Journal of Intellectual Capital, 5(1), p. 128.

27 Akdemir, A. (1998), "Entelektüel Sermaye Konseptinin İşletmecilik Anlayışındaki Dönüşümleri", Süleyman Demirel Üniversitesi İktisadi ve İdari Bilimler Fakültesi Dergisi, pp. 67-98.

28 Ordóñez de Pablos, P. (2004), "Measuring and reporting structural capital: Lessons from European learning firms", Journal of Intellectual Capital, 5(4), pp. 629-647.

29 Abeysekera, I. (2003), "Intellectual accounting scorecard: Measuring and reporting intellectual capital", Journal of American Academy of Business, 3(1), p. 422. 
ent of personnel to create solutions for their clients. Then, human capital is equivalent to personal knowledge inventory of organizations reflected by their employees. ${ }^{30}$ So, investing in human capital is very important to obtain desired financial results in the long run ${ }^{31}$ and to have an innovative character ${ }^{32}$. But of course human capital can only be rented since personnel of all firms take their abilities, knowledge and experiences with them when they transfer to another company. ${ }^{33}$ Then, structural capital is the element, which transforms know-how into the property of the group. Thus, structural capital supports human capital to get more productive and it is an anchor in the value creation process. ${ }^{34}{ }^{35}$ Also, customer capital helps a company to sustain relationships with its clients successfully. ${ }^{36} 37$ Customer capital is actually tough to determine because it is concerned with customer loyalty, relationship with suppliers, agreements and sponsorships. ${ }^{38}$

Also, intellectual capital is a broad term, which consists knowledge, patents, brands, trademark, competition, knowledge, customer relatioships, technology, research and devel-

30 Bontis, N. and Fitz-enz, J. (2002), "Intellectual capital ROI: a causal map of human capital antecedents and consequents", Journal of Intellectual Capital, 3(3): 224.

31 Johanson, U. (2003), "Why are capital market actors ambivalent to information about certain indicators in intellectual capital?", Accounting, Auditing \& Accountability Journal, 16(1), p. 36.

32 Riahi-Belkaouri, A. (2003), "Intellectual capital and firm performance of US multinational Firms", Journal of Intellectual Capital, 4(2), p. 217.

33 Flamholtz, E. G, Bullen, M. L. And Hua, W. (2002), "Human resource accounting: historical perspective and future implications", Management decision, 40 (10), pp. 947-954

34 Daum, J. (2001), "Interview with Leif Edvinsson", Intellectual capital: The new wealth of Corporation, p. 1.

35 Steward, T. A.(1997), "Intellectual capital: the new wealth of organisations: Knowledge Management", Nicholas Brearley Publishing, USA, p. 5.

36 Stewart, T. A. (1997), "Intellectual capital: The new wealth of organisations", Knowledge Management, 67, p. 5.

37 Swart, J. (2006), "Intellectual capital: Disentangling an enigmatic concept", Journal of Intellectual Capital, 7(2), p. 137.

38 Lev, B, Cañibano, L. and Marr, B. (2005), "An accounting perspective on intellectual capital", Oxford, Elsevier, pp. 42-55. 
opment. ${ }^{39}$ Thus, intellectual capital is the total sum of intangible assets. ${ }^{40}$ Organizations with rich human capital, structural capital and relational (customer) capital are observed to have higher return on assets compared to the industry average. ${ }^{41}$

Several stakeholders in the market are indeed getting much more informed about the existence of intellectual capital compared to previous years, since organizations relying to intangible assets are climbing. ${ }^{42}$ Informing stakeholders is indeed essential for better invesment and decision options. Plus, it is also advantageous for firms with a strong intellectual capital to run accounting, reporting and measurement practices to show their real value. ${ }^{43}$

The literature review also shows that, large scaled firms tend to present information on their official websites related to intellectual capital, production efficiency, corporate governance and social responsibility. In addition, analyst following are determined as a significant factor and explanatory variable for two separate disclosures, which are intellectual capital and innovation/development. Moreover, the financial situation of an organization is found to affect intellectual capital disclosure on web. The reason is, companies with higher debts step away more from sharing their financial information on the Internet,

39 Roslender, R. (2000), "Accounting for intellectual capital: A contemporary management accounting perspective", Management Accounting, 78(3),pp. 34-37.

40 Mouritsen J, Larsen H. T. and Bukh, P. N. (2001), "Valuing the future: Intellectual capital supplements and Skandia", Accounting, Auditing \& Accountability Journal, 14(4), p.400.

41 Rodov I. and Leliaert P. (2002), "FiMIAM: Financial method of intangible assets measurement", Journal of Intellectual Capital, 3(3), p. 328.

42 Organisation for Economic Co-operation and Development (OECD), Corporate Affairs Division, Directorate for Financial and Enterprise. (2006), "Intellectual Assets and value creation: Implications for corporate reporting", Paris, http://www.oecd.org/dataoecd/2/40/37811196.pdf.

43 Seetharaman A, Balachandran M. and Saravanan A. S. (2002), "Accounting treatment of goodwill: Yesterday, today and tomorrow: Problems and prospects in the international perspective", Journal of Intellectual Capital, 5(1), p. 132. 
since this triggers a perception that these firms invest less in intellectual capital because of their debts. ${ }^{44}$

In a study, Alali and Ramirez did examine the disclosure practices on the websites of firms listed on the Buenos Aires Stock Exchange. Internet reporting implementations of 84 publicly traded companies were included in their research. They found that, firms belonging to the financial and insurance, services and mining industries were disclosing more financial and non-financial data such as intellectual capital on their official websites compared to firms belonging to other industries. Their study also revealed that, approximately $71 \%$ of firms in the financial and insurance sectors were audited by Big 4. Finally, firms operating in the energy sector such as mining industry were determined to present more disclosure about social responsibility, in order to change the perception of public that they harm the environment. ${ }^{45}$

Finally, Cormier, LeDoux and Magnan did run a study on Canada's largest publicly traded firms in 2009. They focused on Web disclosure of those firms. Their research found that, intellectual capital disclosure on web was linked to social responsibility disclosure. Also, financial performance and corporate governance disclosure were tightly related. Then, firms providing disclosure on innovation, growth and development had high capability websites. ${ }^{46}$

\section{Data and Methodology}

In this chapter, the details of data analysis methods and the methodologies implemented over the data are explained. The

44 Aerts, W., Cormier, D., Gordon, I. M., Magnan, M. (2006), "Performance disclosure on the web: an exploration of the impact of managers' perceptions of stakeholder concerns", The International Journal of Digital Accounting Research, Vol. 6, No: 12, pp. 180-181.

45 Alali, F. and Romero, F. (2012), "The use of the Internet for corporate reporting in the Mercosur (Southern common market): The Argentina case", Advances in Accounting, incorporating Advances in International Accounting, Vol. 28, p. 157

46 Cormier, D., LeDoux, M. J., Magnan, M. (2009), "The Use of Websites as a Dicclosure Platform for Corporate Performance", Vol. 10, p. 1. 
data correlation is built on the WinQSB software which is freely available ${ }^{47}$.

\section{a. Methodology}

This section covers the background of methods implemented in the correlation analysis. The correlation is built on WinQSB forecasting and linear regression options.

Linear regression is built over a linear function which can be written as in equation (1).

$$
y=\alpha+\beta x
$$

In the equation, the $x$ is variable, $a$ and $b$ are the constants of the equation. For example in a 2D Cartesian space, the samples can be modeled as in figure 5.

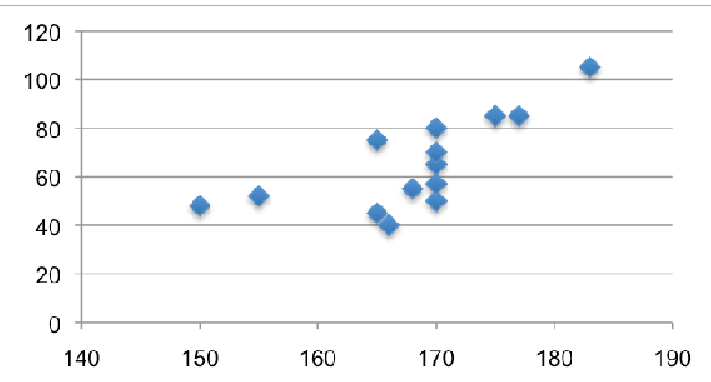

Figure 1. Sample Data Set for Linear Regression

In the linear regression method, the idea is finding the best linear equation where the error rates are minimized.

$y_{i}=\alpha+\beta x_{i}, i=1, \ldots, n$

Error rates are the distance from sample to the linearly modeled line.

For the given example in figure 6, the linear regression model of the line is as follows:

47 http://dl.acm.org/citation.cfm?id= 1208603 


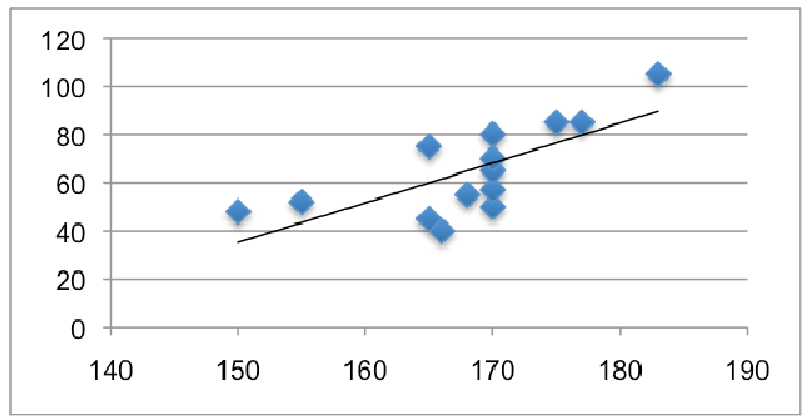

Figure 2. Sample Linear Regression Model for the Given Dataset

The line in figure 7 is the best line which can be drawn with the total minimum error rate.

The error rate calculation is demonstrated in figure 7.

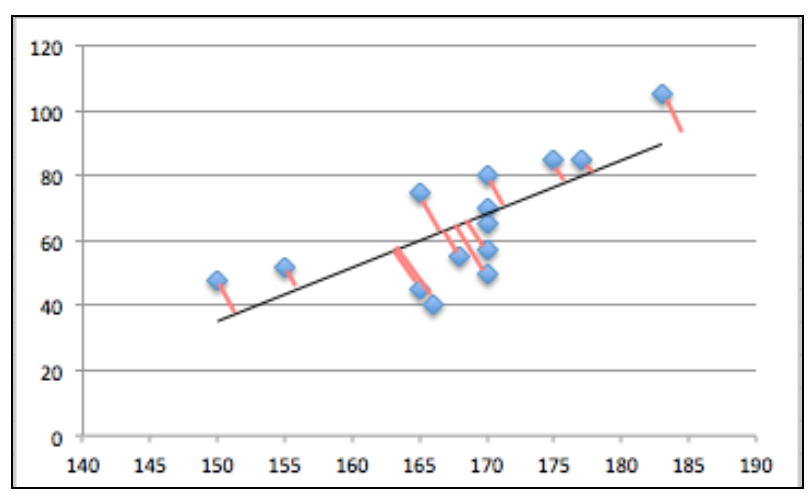

Figure 3. Demonstration of Error Rates in Linear Regression

The error rate calculation can be made with equation (2)

$y_{i}=\alpha+\beta X_{i}+\varepsilon_{i}, i=1, \ldots, n$

The $\varepsilon$ value for each of the sample in the data set is the error rate or the distance for the given linear equation and the sample. 
Since we try to figure out the linear equation from the given data set, we can state that the slope variable $\beta$ can be rewritten as in equation (3).

$$
\beta_{\text {overall }}=\frac{\frac{1}{n} \sum_{i=1}^{n}\left(x_{i}-\bar{x}\right)\left(y_{t}-\bar{y}\right)}{\frac{1}{n} \sum_{i=1}^{n}\left(x_{i}-\bar{x}\right)^{2}}
$$

In equation 3 , the overall value of $\beta$ is calculated through each of the samples. The equation simply calculates the average of the distance between data set, which can be rewritten as the $(x, y)$ coordinates and the projection of data set over the linear equation $(\bar{x}, \bar{y})$.

The average formulation on equation (3) can be rewritten as the statistical notation in equation (4).

$$
\beta_{x}=\frac{\operatorname{Cov}\left[x_{i}, y_{i}\right]}{\operatorname{Var}\left[x_{i}\right]}
$$

\section{b. Data Set}

Data for this research are gathered from company annual reports, financial statements (balance sheet and income statement), firm official websites, KAP web page (kap.gov.tr), Morningstar financial website (morningstar.com), Yahoo Finance (finance.yahoo.com), Businessweek web page (investing.businessweek.com), iss Yatıım website (isyatirim.com.tr) and also the Google Trends website (https://www.google.com.tr/trends/?hl=tr)

The study includes market to book values (MV/BV), value added (VA), tangible (physical) capital (TC $=P C$ ), financial capital (FC), capital employed (CE), capital employed efficiency (CEE), human capital (HC), human capital efficiency (HCE), structural capital (SC), structural capital efficiency (SCE), value added intellectual capital (VAIC) and Google trends (GT) values. 
Specific and separate formulas are used to calculate each of the mentioned values:

Market Value $(\mathrm{MV})$ = Price per share $\mathrm{X}$ Number of firm shares in the market

Book Value $(\mathrm{BV})=$ (Current Assets + Fixed Assets) - (Short-Term Liabilities + Long-Term Liabilities)

Value Added $(\mathrm{VA})=$ Revenue - Expenditures

Financial Capital $(\mathrm{FC})=$ Cash and Securities + Derivative Financial Instruments + Trade Receivables + Inventories + Other Current Assets

Capital Employed (CE) = Tangible Capital + Financial Capital

Capital Employed Efficiency (CEE) = Value Added (VA) / Capital Employed (CE)

Human Capital $(\mathrm{HC})=$ Personnel Expenses (Investments and expenses made for employees)

Human Capital Efficiency $(\mathrm{HCE})=$ Value Added (VA) / Human Capital (HC)

Structural Capital (SC) = Value Added (VA) - Human Capital $(\mathrm{HC})$

Structural Capital Efficiency (SCE) = Structural Capital (SC) / Value Added (VA)

Value Added Intellectual Capital (VAIC) $=$ CEE + HCE + SCE

Values above are calculated for each BIST 30 companies taking advantage of formulas. Also, the values are computed for three years respectively, which are 2010, 2011 and 2012. But, the year 2013 is not included to the study since annual reports, operational reports, balance sheets and income states (financial statements) are completed, published and shared with the public on December 31 every year. Finally, data for this research are statistically analyzed and correlations are tested using the WinQSB package program. 


\section{Statistical and Accounting Analysis}

The data, calculations and values are first entered to the WinQSB software for statistical and accounting analysis. There is a total of 90 observations for the study, that are three years $(2010,2011$ and 2012) for each of the 30 companies. Also, the research consists 14 factors for analysis.

After entering the data, calculations and values to the WinQSB statistical package program, correlation analysis are tested in the next step. Correlations test the relationship and direction of relationship between variables (factors). According to correlation analysis theory, a correlation of 0,0 - 0,2 means very weak (very low) relationship and a correlation of 0,2 - 0,4 means weak (low) relationship. Furthermore, correlation between $0,4-0,7$ stands for moderate (considerable) relationship and correlation between 0,7 - 0,9 explains a strong (high) relationship. Finally, the correlation of $0,9-1,0$ is considered as a very strong (very high) relationship. ${ }^{48}$

48 Kayahan, C. (2008), "Işletmelerde Bir Avantaj Unsuru Olarak Kur Korelasyonlarının Kullanımı", Yönetim ve Organizasyon Dergisi, Vol.: 15, No: 1, p. 78. 


\begin{tabular}{|c|c|c|c|}
\hline 09-29-2013 & Variable & Variable & Correlation \\
\hline 1 & Fira & Term & 0 \\
\hline 2 & Fing & MV/BV & 0 \\
\hline 3 & Firm & VA & 0 \\
\hline 4 & Fing & $\mathrm{IC}[\mathrm{PC}]$ & 0 \\
\hline 5 & Fine & $\mathrm{FC}$ & 0 \\
\hline 6 & Fine & CE & 0 \\
\hline 7 & Firm & CEE & 0 \\
\hline 8 & Firm & HC & 0 \\
\hline 9 & Finm & HCE & 0 \\
\hline 10 & Five & SC & 0 \\
\hline 11 & Fing & SCE & 0 \\
\hline 12 & Firm & VAIC & 0 \\
\hline 13 & Firm & GI & 0 \\
\hline 14 & Term & MV/BV & $6,179955 E-02$ \\
\hline 15 & Term & VA & $-1,377406 \mathrm{E}-02$ \\
\hline 16 & Term & $\mathrm{IC}(\mathrm{PC})$ & $-7,0639993 \mathrm{E}-02$ \\
\hline 17 & Term & FC & -0.1474071 \\
\hline 18 & Term & CE & -0.2120351 \\
\hline 19 & Term & CEE & $3,607735 \mathrm{E}-02$ \\
\hline 20 & Term & HC & $1,884128 \mathrm{E}-02$ \\
\hline 21 & Term & HCE & $-1,009589 E-02$ \\
\hline 22 & Term & SC & $2,456894 \mathrm{E}-02$ \\
\hline 23 & Term & SCE & -0.1057284 \\
\hline 24 & Term & VAIC & $-8,809591 \mathrm{E}-02$ \\
\hline 25 & Term & GT & $-0,109392$ \\
\hline 26 & MV/BV & VA & $5,854166 \mathrm{E}-02$ \\
\hline 27 & MV/BV & $\mathrm{TC}[\mathrm{PC}]$ & 0.2971227 \\
\hline 28 & MV/BV & FC & $6.048715 E-02$ \\
\hline 29 & MV/BV & CE & -0.0920875 \\
\hline 30 & MV/BV & CEE & $-9,154076 E-02$ \\
\hline 31 & MV/BV & $\mathrm{HC}$ & 0,141445 \\
\hline 32 & MV/BV & HCE & $9.279916 E-02$ \\
\hline 33 & MV/BV & SC & -0.2191535 \\
\hline 34 & MV/BV & SCE & -0.212305 \\
\hline 35 & MV/BV & VAIC & $-0,1256085$ \\
\hline 36 & MY/BY & GI & 0.3025628 \\
\hline
\end{tabular}

Figure 4. Correlation Analysis 1-36 Among the Variables (Factors) 


\begin{tabular}{|c|c|c|c|}
\hline $09-29-2013$ & Variable & Variable & Conelation \\
\hline 30 & MV/BV & CEE & $-9,154076 E-02$ \\
\hline 31 & MV/BV & HC & 0.141445 \\
\hline 32 & MV/BV & HCE & $9.279916 E-02$ \\
\hline 33 & MV/BV & SC & -0.2191535 \\
\hline 34 & $M V / B V$ & SCE & $-0,212305$ \\
\hline 35 & $M V / B V$ & VAIC & $-0,1256085$ \\
\hline 36 & MV/BV & GT & 0,3025628 \\
\hline 37 & VA & TC[PC] & 8.599272E-02 \\
\hline 38 & VA & FC & 0.0508411 \\
\hline 39 & VA & CE & $-1.169776 E-02$ \\
\hline 40 & VA & CEE & 0,269226 \\
\hline 41 & VA & $\mathrm{HC}$ & 0,080272 \\
\hline 42 & VA & HCE & 0.2625776 \\
\hline 43 & VA & SC & 0.1530694 \\
\hline 44 & VA & SCE & -0.139532 \\
\hline 45 & VA & VAIC & $6.236329 E-02$ \\
\hline 46 & VA & GT & $-7,658027 \mathrm{E}-02$ \\
\hline 47 & $\mathrm{TC}[\mathrm{PC}]$ & FC & 0,3281146 \\
\hline 48 & $\mathrm{TC}[\mathrm{PC}]$ & CE & 7.719001E-02 \\
\hline 49 & TC[PC] & CEE & -0.216512 \\
\hline 50 & TC(PC) & $\mathrm{HC}$ & $-3.156256 E-02$ \\
\hline 51 & $\mathrm{TC}[\mathrm{PC}]$ & HCE & $-8.236752 E-03$ \\
\hline 52 & TC(PC) & SC & $-8,934622 E-02$ \\
\hline 53 & $\mathrm{TC}(\mathrm{PC}]$ & SCE & $-3,159061 E-02$ \\
\hline 54 & TC[PC] & VAIC & $-4,10348 E-03$ \\
\hline 55 & $\mathrm{TC}[\mathrm{PC}]$ & GT & 0.0858459 \\
\hline 56 & FC & CE & 0.2184134 \\
\hline 57 & FC & CEE & $-1,905043 E-02$ \\
\hline 58 & FC & $\mathrm{HC}$ & $-0,2573765$ \\
\hline 59 & FC & HCE & 0,2354473 \\
\hline 60 & FC & SC & $3.938232 E-02$ \\
\hline 61 & FC & SCE & -0.1137795 \\
\hline 62 & FC & VAIC & $2,611383 E-02$ \\
\hline 63 & $\mathrm{FC}$ & GT & $-4.776147 \mathrm{E}-02$ \\
\hline 64 & CE & CEE & $-1,310335 E-02$ \\
\hline 65 & $\mathrm{CE}$ & $\mathrm{HC}$ & -0.1759006 \\
\hline
\end{tabular}

Figure 5. Correlation Analysis 30-65 Among the Variables (Factors) 


\begin{tabular}{|c|c|c|c|}
\hline 09-29-2013 & Variable & Variable & Correlation \\
\hline \begin{tabular}{|l|}
56 \\
\end{tabular} & FC & CE & 0.2184134 \\
\hline 57 & FC & CEE & $-1.905043 E-02$ \\
\hline 58 & FC & HC & -0.2573765 \\
\hline 59 & FC & HCE & 0,2354473 \\
\hline 60 & FC & SC & $3,939232 \mathrm{E}-02$ \\
\hline 61 & FC & SCE & -0.1137795 \\
\hline 62 & FC & VAIC & $2.611383 E-02$ \\
\hline 63 & FC & GI & $-4.776147 \mathrm{E}-02$ \\
\hline 64 & CE & CEE & $-1,310335 \mathrm{E}-02$ \\
\hline 65 & CE & HC & $-0,1759006$ \\
\hline 66 & CE & HCE & $5,245858 \mathrm{E}-02$ \\
\hline 67 & CE & SC & $3.665702 E-02$ \\
\hline 68 & CE & SCE & $3,6875888-02$ \\
\hline 69 & CE & VAIC & $5,370747 \mathrm{E}-02$ \\
\hline 70 & CE & GT & $-0,235651$ \\
\hline 71 & CEE & HC & 0,1397313 \\
\hline 72 & CEE & HCE & 0.4849565 \\
\hline 73 & CEE & SC & 0.1641719 \\
\hline 74 & CEE & SCE & -0.2995893 \\
\hline 75 & CEE & VAIC & $-7,254557 \mathrm{E}-02$ \\
\hline 76 & CEE & GT & $-0,1906997$ \\
\hline 77 & HC & HCE & $5.592993 E-02$ \\
\hline 78 & $\mathrm{HC}$ & SC & -0.2385793 \\
\hline 79 & $\mathrm{HC}$ & SCE & -0.1195503 \\
\hline 80 & $\mathrm{HC}$ & VAIC & $-0,260779$ \\
\hline 81 & HC & GI & 0.1798479 \\
\hline 82 & HCE & SC & $-9.578099 \mathrm{E}-02$ \\
\hline 83 & HCE & SCE & -0.5845653 \\
\hline 84 & HCE & VAIC & -0.2892206 \\
\hline 85 & HCE & GI & $-5,101155 E-02$ \\
\hline 86 & SC & SCE & 0,3447512 \\
\hline 87 & SC & VAIC & 0.2870952 \\
\hline 88 & SC & GT & $-6.077979 E-02$ \\
\hline 89 & SCE & VAIC & 0.3573539 \\
\hline 90 & SCE & GT & $-1,250593 E-02$ \\
\hline 91 & YAIC & GI & $-9.6838947 E-02$ \\
\hline
\end{tabular}

Figure 6. Correlation Analysis 56-91 Among the Variables (Factors)

Market to Book Value (MV / BV) method and Value Added Intellectual Coefficient (VAIC) technique are two common ways to measure intellectual capital of firms. By the help of these two methods, it is possible to calculate the human capital and structural capital of organizations. In regards to intellectual capital accounting of BIST30 firms, it is possible to prepare intellectual capital balance sheets. Since there exists a total of 90 observations and 30 companies for the research, it is logi- 
cal and feasible to prepare the intellectual capital balance sheets for selected and eye-catching firms as examples. $16,30)$

BiM Company (Firm with the highest MV/BV for 2012-

BiM Human Capital $(2010)=371.661 .000 \mathrm{TL}$

BiM Structural Capital $(2010)=-126.021 .000 \mathrm{TL}$

BiM Intellectual Capital (2010) = BiM Human Capital (2010) + BiM Structural Capital (2010) $=371.661 .000$ 126.021.000 TL

Intellectual Capital Balance Sheet of BiM. (2010)

Assets

$(\mathrm{TL})$

Liabilities

\begin{tabular}{|lr|lc|}
\hline Intellectual Capital (IC) Assets & \multicolumn{2}{l|}{ Intellectual Capital (IC) Liabilities and Equity } \\
Structural Capital & $-126.021 .000 \mathrm{TL}$ & IC Liabilities: & 0 \\
Human Capital: & $371.661 .000 \mathrm{TL}$ & IC Equity: & $245.640 .000 T L$ \\
TOTAL IC ASSETS & $245.640 .000 \mathrm{TL}$ & TOTAL IC LIAB. AND EQUITY & $245.640 .000 \mathrm{TL}$ \\
\hline
\end{tabular}

Intellectual Capital Balance Sheet of BiM. (2011)

Assets

(TL)

Liabilities

\begin{tabular}{|lr|ll|}
\hline Intellectual Capital (IC) Assets & \multicolumn{2}{l|}{ Intellectual Capital (IC) Liabilities and Equity } \\
Structural Capital & -142.968 .000 TL & IC Liabilities: & 0 \\
Human Capital: & 441.878 .000 TL & IC Equity: & $298.910 .000 T L$ \\
TOTAL IC ASSETS & 298.910 .000 TL & TOTAL IC LIAB. AND EQUITY & 298.910 .000 TL \\
\hline
\end{tabular}

Intellectual Capital Balance Sheet of BiM. (2012)

Assets

(TL)

Liabilities

\begin{tabular}{|lc|ll|}
\hline Intellectual Capital (IC) Assets & \multicolumn{2}{|l|}{ Intellectual Capital (IC) Liabilities and Equity } \\
Structural Capital & $-209.158 .000 \mathrm{TL}$ & IC Liabilities: & 0 \\
Human Capital: & $540.479 .000 \mathrm{TL}$ & IC Equity: & $331.321 .000 T$ \\
TOTAL IC ASSETS & $331.321 .000 \mathrm{TL}$ & TOTAL IC LIAB. AND EQUITY & $331.321 .000 \mathrm{TL}$ \\
\hline
\end{tabular}

Sabancı Holding (Firm with the highest Value Added for $2012-5.458 .636 .000 \mathrm{TL})$

Intellectual Capital Balance Sheet of Sabancı Holding (2010)

Assets

(TL)

Liabilities 
Intellectual Capital (IC) Assets

Structural Capital

Human Capital:

TOTAL IC ASSETS

Intellectual Capital Balance Sheet of Sabancı Holding (2011)

(TL)

Liabilities

\begin{tabular}{|lr|ll|}
\hline Intellectual Capital (IC) Assets & Intellectual Capital (IC) Liabilities and Equity \\
Structural Capital & $-1.465 .956 .000 ~ T L$ & IC Liabilities: & 0 \\
Human Capital: & $3.319 .003 .000 \mathrm{TL}$ & IC Equity: & $1.853 .047 .000 \mathrm{TL}$ \\
TOTAL IC ASSETS & $1.853 .047 .000 \mathrm{TL}$ & TOTAL IC LIAB. AND EQUITY & $1.853 .047 .000 \mathrm{TL}$ \\
\hline
\end{tabular}

Intellectual Capital Balance Sheet of Sabancı Holding (2012)

Assets

Intellectual Capital (IC) Assets

Structural Capital

Human Capital:

TOTAL IC ASSETS

(TL)

Liabilities

Emlak Konut (Firm with the highest VAIC for 2012 - 44, 14)

Intellectual Capital Balance Sheet of Emlak Konut (2010)
(TL)

Liabilities

\begin{tabular}{|lr|ll|}
\hline \multicolumn{2}{|l|l|l|}{ Intellectual Capital (IC) Assets } & \multicolumn{2}{l|}{ Intellectual Capital (IC) Liabilities and Equity } \\
Structural Capital & $541.439 .000 \mathrm{TL}$ & IC Liabilities: & 0 \\
Human Capital: & $12.874 .000 \mathrm{TL}$ & ICEquity: & $554.313 .000 \mathrm{TL}$ \\
TOTAL IC ASSETS & $554.313 .000 \mathrm{TL}$ & TOTAL IC LIAB. AND EQUITY & $554.313 .000 \mathrm{TL}$ \\
\hline
\end{tabular}

Intellectual Capital Balance Sheet of Emlak Konut (2011)

Assets

Intellectual Capital (IC) Assets

Structural Capital

Human Capital:

TOTAL IC ASSETS

Intellectual Capital Balance Sheet of Emlak Konut (2012)
(TL)

Liabilities

Assets

(TL)

Liabilities 


\begin{tabular}{|lr|lc|}
\hline Structural Capital & 503.609 .000 TL & IC Liabilities: & 0 \\
Human Capital: & 19.793 .000 TL & IC Equity: & $523.402 .000 \mathrm{TL}$ \\
TOTAL IC ASSETS & $523.402 .000 \mathrm{TL}$ & TOTAL IC LIAB. AND EQUITY & $523.402 .000 \mathrm{TL}$ \\
\hline
\end{tabular}

İş Bankası A. Ş. (Firm with the highest Google Trends for $2011-100)$

Intellectual Capital Balance Sheet of İş Bankası A. Ş. (2010)

Assets (TL) Liabilities

\begin{tabular}{|ll|lc|}
\hline \multicolumn{2}{|l|l}{ Intellectual Capital (IC) Assets } & \multicolumn{3}{l|}{ Intellectual Capital (IC) Liabilities and Equity } \\
Structural Capital & $1.070 .645 .000 \mathrm{TL}$ & IC Liabilities: & 0 \\
Human Capital: & $1.911 .565 .000 \mathrm{TL}$ & ICEquity: & $2.982 .210 .000 \mathrm{TL}$ \\
TOTAL IC ASSETS & $2.982 .210 .000 \mathrm{TL}$ & TOTAL IC LIAB. AND EQUITY & $2.982 .210 .000 \mathrm{TL}$ \\
\hline
\end{tabular}
(2011)

Intellectual Capital Balance Sheet of iş Bankası A. Ş. Assets

(TL)

Liabilities

\begin{tabular}{|lr|ll|}
\hline \multicolumn{2}{|l|l}{ Intellectual Capital (IC) Assets } & \multicolumn{3}{l|}{ Intellectual Capital (IC) Liabilities and Equity } \\
Structural Capital & $512.440 .000 \mathrm{TL}$ & IC Liabilities: & 0 \\
Human Capital: & $2.155 .047 .000 \mathrm{TL}$ & IC Equity: & $2.667 .487 .000 \mathrm{TL}$ \\
TOTAL IC ASSETS & $2.667 .487 .000 \mathrm{TL}$ & TOTAL IC LIAB. AND EQUITY & $2.667 .487 .000 \mathrm{TL}$ \\
\hline
\end{tabular}
(2012)

Intellectual Capital Balance Sheet of iş Bankası A. Ş. Assets Liabilities

\begin{tabular}{|ll|ll|}
\hline \multicolumn{2}{|l|}{ Intellectual Capital (IC) Assets } & \multicolumn{2}{l|}{ Intellectual Capital (IC) Liabilities and Equity } \\
Structural Capital & $1.111 .439 .000 \mathrm{TL}$ & IC Liabilities: & 0 \\
Human Capital: & $2.198 .868 .000 \mathrm{TL}$ & IC Equity: & $3.310 .307 .000 \mathrm{TL}$ \\
TOTAL IC ASSETS & $3.310 .307 .000 \mathrm{TL}$ & TOTAL IC LIAB. AND EQUITY & $3.310 .307 .000 \mathrm{TL}$ \\
\hline
\end{tabular}

\section{Results (Findings)}

The study reveals very significant and critical results. First of all, Market to Book Value (MV / BV) indicates how many times a firm's market value exceeds the value of its equity. The highest MV / BV ratio belongs to BIM company in 2012. The organization's market value was 16 times its equity in 2012 . On the other 
hand, MV / BV ratio was lowest for the Kardemir and lipek Doğal Enerji firms in 2012. Both of the mentioned corporations experienced a MV / BV rate of 0,20. Since the value is lower than 1 for these enterprises, only discounted investments are made to the equity of Kardemir and Ijpek Doğal Enerji.

Based on our research, value added (VA) is highest for Sabanci Holding with a sum of 5.458.636.000 TL in 2012. Since $V A$ is calculated by subtracting expenditures from revenues, a high VA sum is always appreciated. At this point, it should be noted that the VA was lowest for Doğan Holding with a sum of 962.174.000 TL in 2011.

Concerning tangible (physical) capital (TC $=\mathrm{PC}$ ), Koç Holding takes the lead with a sum of 14.266.871.000 TL in 2012. The company's machinery, equipment and other tangibles were very high in the mentioned year. However, Bank Asya was observed as the firm with lowest tangible (physical) capital in 2011 (1 12.793.000 TL). In fact, this is not surprising since Bank Asya operates in the banking-finance industry. This value is actually higher in organizations which operate in the manufacturing-production sectors.

In regards to financial capital (FC), Sabanci Holding ranks first with a sum of 85.418.1 19.000 TL in 2012. Financial capital includes the value of financial tools such as stocks (shares), bills, bonds and credits that are subject to financial investments. Thus, it is an important indicator. Koza Altın had the least financial capital among BIST 30 for all observations in 2010, with a sum of $253.616 .534 \mathrm{TL}$.

Then, the study includes capital employed (CE), which is the sum of tangible capital (physical capital) and financial capital. Sabanci Holding comes first in terms of CE with a sum of 92.331.864.000 TL in 2012. On the opposite side, Koza Altın is observed to have the lowest CE in 2010 with a value of 515.275.534 TL. 
Next, research points out that Sabancı Holding has the most rich human capital (HC) among BIST 30 firms with a sum of 3.865.834.000 TL in 2012. This means, Sabancl Holding makes the highest investments and spending to its employees compared to other organizations. But, Emlak Konut owns the most weak human capital among BIST 30 firms with a sum of 12.874.000 TL in 2010. In other words, Emlak Konut's investments and spending related to its personnel are low when all BIRST 30 organizations are considered.

After that, the strongest structural capital (SC) belongs to Akbank with a sum of 1.979.012.000 TL in 2010. Structural capital is computed by subtracting human capital from value added. Thus, it is definitely a significant and critical indicator. The main reason why Akbank has a very strong structural capital is actually hidden behind the banking sector. Generally, the banks make serious investments to ATM machines, networks, intranets, online banking, software, hardware innovative technologies, patents, copyrights, research and development (R\&A). Thus, it is common for banks to have a high structural capital. Still, Akbank is a special eye-catching figure in the banking industry in terms of structural capital. On the contrary, Kardemir has the lowest structural capital among BIST 30 firms with a sum of $1.850 .978 .863 \mathrm{TL}$ in 2010 .

Besides, research reflects some notable information regarding value added intellectual coefficients (VAIC). As well known, VAIC is calculated by adding up human capital efficiency, structural capital efficiency and capital employed efficiency. Thus, a high VAIC is always preferred. Findings underline the fact that, Emlak Konut firm has the highest VAIC in 2010 with a value of 44 . Yet, Şişecam has the lowest VAIC among all BIST 30 with a value of -29 in 2012 , which is an undesired result for company management.

Moreover, results related to Google Trends (GT) make it clear that, iş Bankası A.Ş. ranks first with a score of 100 among BIST 30. This means that, İş Bankası A.Ş. is the most referred and 
typed organization on Google Search Engine. The organization also has a rising trend in this regard. However, ipek Doğal Enerji attracts attention as the least searched, referred and typed company on Google among BIST 30. The firm has a score of 0 in 2010.

Furthermore, investigating the correlation results among variables presents that, there exists no strong or very strong relationship among the indicators. The highest correlation experienced is Correlation number 83 . A correlation of -0.58 is observed between Human Capital Efficiency (HCE) and Structural Capital Efficiency (SCE). That is a negative moderate relationship. Also, another moderate relationship is observed under Correlation number 72. Here, there is a correlation of +0.48 between Capital Employed Efficiency (CEE) and Human Capital Efficiency (HCE). In other words, a positive moderate relationship is calculated and perceived. However, the remaining correlations among market to book value (MV/BV), value added (VA), tangible capital (physical capital) (TC = PC), financial capital (FC), capital employed (CE), capital employed efficiency (CEE), human capital (HC), human capital efficiency (HCE), structural capital (SC), structural capital efficiency (SCE), value added intellectual coefficient (VAIC) and Google trends (GT) are all either weak or very weak.

Finally, the journal entries (see appendix) and accounting balance sheets prepared in this study for selected firms show that, BiM's (firm with highest market to book value in 2012 16,30) intellectual capital performance was highest in 2012. The firm had intellectual assets and intellectual capital with a sum of 331.321.000 TL in 2012. Likewise, BiM's structural capital and human capital was strongest in 2012. The mentioned year revealed a total of 331.321.000 TL intellectual capital assets for the firm.

Journal entries and intellectual capital balance sheets for Sabancı Holding (firm with the highest value added for 2012 5.458.636.000 TL) show that, company attained the best per- 
formance in 2012. Sabancl Holding had 5.458.636.000 TL of intellectual assets and intellectual capital in 2012. Organization's intellectual capital balance sheet was promising in 2012, with a structural capital of 1.592.802.000 TL and a human capital of 3.865.834.000 TL. Thus, total intellectual capital assets of 5.458.636.000 was observed on the intellectual capital balance sheet in 2012.

Based on the journal entries of Emlak Konut (firm with the highest VAIC for $2012-44,14)$, the most successful year produced intellectual assets and intellectual capital of 554.313.000 TL in 2010. Parallel to the journal entry record, intellectual capital balance sheet of Emlak Konut dated 31.12 .2010 is observed as the best. The company had a structural capital of 541.439.000 TL and a human capital of 12.874.000 TL that year, which resulted in total intellectual capital assets of 554.313.000 TL in 2010.

At last, investigating the journal entries for iş Bankası A. Ş. (firm with the highest Google Trends for 2011 - 100) helps to understand that, organization had the best achievement in terms of intellectual assets and intellectual capital in 2012, with a sum of 3.310.307.000 TL. Again, intellectual capital balance sheet of iş Bankası A.Ş. dated 31.12.2012 indicate that, company was most victorious in the mentioned year. Iş Bankası A. Ş. had a structural capital of 1.111.439.000 TL and a human capital of $2.198 .868 .000 \mathrm{TL}$ in 2012. These two intellectual capital components did lead to total intellectual capital assets of 3.310.307.000 TL at the end of 2012 financial year.

\section{Conclusion}

The implementation (practical) part of this study served as a model and example for accounting and measurement of intellectual capital. For measuring the intellectual capital of BIST 30 companies, market to book value (MV / BV) method and value added intellectual capital (VAIC) technique were 
implemented. Moreover, the research benefited from correlation analysis for testing the relationship among book value (MV/BV), value added (VA), tangible capital (physical capital) ( $\mathrm{TC}=\mathrm{PC}$ ), financial capital (FC), capital employed (CE), capital employed efficiency (CEE), human capital (HC), human capital efficiency (HCE), structural capital (SC), structural capital efficiency (SCE), value added intellectual coefficient (VAIC) and Google trends (GT).

It is thought that the prepared journal entries (see appendix) as well as intellectual capital balance sheets are beneficial for stakeholders who consider investing in BIST 30 firms. Relevant journal entries and intellectual capital balance sheets are helpful to inform investors with a new tool in addition to the traditional balance sheet and existing journal records. Furthermore, it is considered that journal entries and intellectual capital balance sheets are beneficial for managers since they will result in better and more efficient decision making. It is for sure that, managers with greater and more useful resources will have the ability to make smarter and wiser decisions. So, journal entries and intellectual capital balance sheets that are prepared with this study arm both internal and external stakeholders. In case the journal entries related to intellectual assets and intellectual capital as well as intellectual capital balance sheets are taken into consideration together with traditional financial statements, a better idea will be shaped for all BIST 30 companies.

Finally, correlation results among factors show no strong or very strong relationship among indicators. The highest relationship observed is a correlation of -0.58 between Human Capital Efficiency (HCE) and Structural Capital Efficiency (SCE). Plus, a moderate relationship of +0.48 between Capital Employed Efficiency (CEE) and Human Capital Efficiency (HCE) is in order. But, the remaining correlations among other factors (variables) are at weak or very weak levels. 


\section{Recommendations for Future Studies}

This research delivers and offers detailed information regarding BIST 30 firms by accounting and measurement of intellectual capital in addition to correlation analysis. Future research can also focus on intellectual capital accounting and measurement of other companies belonging to additional indexes, such as the BIST 100. Implementations and practices in today's business world at Turkey indicate that, intellectual capital strength of corporations is not researched sufficiently and adequately. On the other hand, retrieving the big and general picture about firms by accounting and measuring their intellectual capital is critically significant, because several parties are influenced by the operations of enterprises. In this era, even the medium and small scaled organizations run specific international operations abroad and they are tightly related with the globe this way or another way.

Detailed consideration and evaluation of organizations' intellectual capital are now a necessity instead of a luxury, since traditional financial statements and reports are away from reflecting the truth. Thus, accounting and measurement of intellectual capital have become requirements for up-todate and efficient business administration.

We recommend that, future research also take advantage of value added intellectual capital (VAIC) method. The emphasized method supplies reliable, standard and auditable information. Recent research and literature benefits from VAIC method since the supplied data are controllable and verifiable. Thus, VAIC technique symbolizes an objectively verifiable indicator. Because of the underlined reasons, future research must continue to concentrate on the VAIC technique, one of the most popular intellectual capital measurement methods.

Also, new studies can include intellectual capital reports as an element of analysis. Definitely, intellectual capital balance sheets should accompany intellectual capital reports for better results. This research argues that intellectual balance 
sheets are useful to direct and support investors, financial managers, customers, firm owners and other stakeholders. Thus, their usage should be a more frequent practice.

In addition, this study recommends and suggests that intellectual capital accounting and measurement should be run on several different industries simultaneously. This would make it possible to make comparisons and evaluations among different industries. Thus, separate specifications and characteristics of different sectors can be discovered by the help of intellectual capital accounting and measurement.

Besides, research offers that following studies can especially investigate firms based on particular sectors. In other words, new research can focus on market/industry segmentation. This would enable comparing organizations operating in the identical industry. Also, more correct and on target interpretations can be made for both the companies and sector. However, it should be noted that some firms will have unique characteristics and structures.

After that, it will be reasonable for the future study to investigate a longer time interval. When time periods extend, trends and correlations become more meaningful. Also, fewer errors and false determinations will be realized with an increase in time interval. Surely, it is not easy to retrieve data belonging to former periods. This is the leading reason why this study is limited with a period of three years $(2010,2011,2012)$. However, future studies will have the chance to obtain detailed information for following durations, since the number of annual reports and operating reports shared with the public increase every year. For sure, storing and archiving capabilities are also better compared to previous years.

Finally, a future study can consist a higher number of variables in order to test more relationships. In case ties and connections among more variables are investigated, new research will have the ability to reflect up-to-date findings. This would integrate a recent perspective to cause and effect inter- 
relations and new correlations can be discovered. Consequently, complementary methods in addition to market to book value (MV / BV) and value added intellectual coefficient (VAIC) techniques can be integrated into future studies for accounting and measuring intellectual capital.

\section{References}

Abeysekera, I. (2003), "Intellectual accounting scorecard: Measuring and reporting intellectual capital", Journal of American Academy of Business, 3(1), p. 422

Aerts, W., Cormier, D., Gordon, I. M., Magnan, M. (2006), "Performance disclosure on the web: an exploration of the impact of managers' perceptions of stakeholder concerns", The International Journal of Digital Accounting Research, Vol. 6, No: 12, pp. 180-181.

Agndal $\mathrm{H}$, and Nilsson U. (2006), "Generation of Human and Structural Capital: Lessons from Knowledge Management", The Electronic Journal of Knowledge Management, Volume 4 Issue 2, pp 91 - 98, available online at www.ejkm.com.

Akdemir, A. (1998), "Entelektüel Sermaye Konseptinin İșletmecilik Anlayıșındaki Dönüşümleri", Süleyman Demirel Üniversitesi İktisadi ve İdari Bilimler Fakültesi Dergisi, pp. 67-98.

Alali, F. and Romero, F. (2012), "The use of the Internet for corporate reporting in the Mercosur (Southern common market): The Argentina case", Advances in Accounting, incorporating Advances in International Accounting, Vol. 28, p. 157.

Alipour, M. (2012), "The effect of intellectual capital on firm performance: an investigation of Iran insurance companies", Measuring Business Excellence, Vol. 16, Issue: 1, pp.53 - 66.

Bontis, N. and Fitz-enz, J. (2002), "Intellectual capital ROl: a causal map of human capital antecedents and consequents", Journal of Intellectual Capital, 3(3): 224

Borsa İstanbul (2013), "Kamuyu Aydınlatma Platformu", Borsa Istanbul Official Website,

http://borsaistanbul.com/data/kilavuzlar/Borsa_Istanbul_Kamuyu_Aydinla tma_Platformu.pdf (September 25, 2013).

Cormier, D., LeDoux, M. J., Magnan, M. (2009), " The Use of Websites as a Dicclosure Platform for Corporate Performance", Vol. 10, p. 1. 